\title{
СУЧАСНІ УКРАЇНСЬКО-РОСІЙСЬКІ ВІДНОСИНИ У ФОРМАТІ ІНТЕГРАЦІЙНИХ ПЛАНІВ РОСІЙСЬКОЇ ФЕДЕРАЦІЇ
}

\author{
С. С. Троян
}

Tроян C. C. Сучасні українсько-російські відносини у форматі інтеграційних планів Російської Федерації. У статті досліджено специфіку сучасних інтеграційних процесів на пострадянському просторі. Вказано на особливу роль Росії у його підпорядкуванні своєму домінуючому впливу. Відзначені особливості реалій і перспектив України у контексті європейських і євразійських інтеграційних векторів.

Ключові слова: Україна; Російська Федерація; інтеграція; пострадянський простір; Співдружність Незалежних Держав.

Tроян $C$. С. Современные украинско-российские отношения в формате интеграционных планов Российской Федерации. В статье исследована специфика современных интеграционных процессов на постсоветском пространстве. Отмечена особая роль России в его подчинении своему доминирующему влиянию. Определены особенности реалий и перспектив Украины в контексте европейских и евразийских интеграционных векторов.

Ключевые слова: Украина; Российская Федерация; интеграция; постсоветское пространство; Содружество Независимых Государств.

Troyan S. S. Contemporary Ukrainian-Russian Relations in the Format of the Integration Plans of the Russian Federation. The article investigates the specificity of the modern integration processes on the Post Soviet space. The particular role of Russia in the submission to its dominating influence is marked. The author clears up the peculiarities of the realities and perspectives of Ukraine in the context of the European and Eurasian integration vectors.

Keywords: Ukraine; Russian Federation; integration; Post Soviet space; Commonwealth of Independent States.

\section{Вступ}

Створення в грудні 1991 р. Співдружності Незалежних Держав (СНД) не лише підсумувало остаточну дезінтеграцію СРСР, але й визначило особливості генези та еволюції інтеграційних процесів на пострадянському просторі в контексті становлення нової «постбіполярної» системи міжнародних відносин. Постала також проблема визначення векторів розвитку, в тому числі інтеграційних, у рамках СНД, вибору та зайняття пострадянськими міжнародними акторами своєї ніші в новій конфігурації міжнародних відносин і світового порядку. Звідси - у теоретичному та прагматичному ключі - така пильна увага до змісту і направленості інтеграційних процесів взагалі і на пострадянському простоpi зокрема, а також ролі у цих процесах Російської Федерації не лише як надпотужного регіонального геополітичного актора і донедавна держави-учасниці G-8 (участь Росії у роботі держав Великої вісімки була призупинена після російської окупації Криму), але й визначального чинника інтеграційних процесів на просторі СНД, євразійської інтеграції загалом. Пріоритетним фактором успішної реалізації такої політики офіційна Москва розглядає безумовну участь у цій інтеграції України, а, отже, для такого залучення можна і треба скористатися з усього комплексу можливих методів, не виключаючи, свідченням чого є події рубежу лютого - березня 2014 р., відвертої агресії та прямого невмотивованого втручання у внутрішні справи України, використання провокацій і шантажу. 3 боку Російської Федерації це стало грубим порушенням норм міжнародного права, базових положень низки міждержавних договорів і домовленостей (загалом договірно-правова база українсько-російських відносин складає понад 350 міжнародних документів, які регулюють або донедавна регулювали широкий спектр двосторонніх питань).

В сучасних українсько-російських відносинах, які пройшли карколомну еволюцію від стратегічного партнерства до відкритого протистояння і навіть ворожнечі, виокремлюється п'ять етапів:

(C) Троян, С. С., 2016 
I (1991-1997) - становлення та закріплення двосторонніх відносин у результаті підписання «Великого договору»;

II (1997-2004) - розвиток відносин стратегічного партнерства на основі Договору від 31 травня 1997 р. 3 намаганням Москви інтегрувати Україну до євразійського економічного і політичного простору при одночасному збереженні ситуативної напруги в стосунках, прикладом чого став конфлікт довкола острова Тузла в Керченській протоці (2003р.);

III (2005-2009) - певне охолодження відносин на політичному рівні в зв'язку з негативним сприйняттям офіційною Москвою подій і наслідків Помаранчевої революції при збереженні позитивної динаміки росту торгівельно-економічної співпраці;

IV (2010-2013) - розширення співробітництва, прагнення з боку Російської Федерації домогтися організаційно-інституційного включення України в євразійські інтеграційні проекти, виходячи 3 концептуального бачення Кремлем пострадянського простору як «природної зони міждержавної інтеграції Росії»;

V (з лютого 2014 р.) - де-факто інтервенція Росії проти України і російсько-українська «гібридна» війна, наслідком чого стала російська окупація Криму і його включення на основі результатів нелегітимного референдуму до складу Російської Федерації, підтримка (інформаційна, військова, гуманітарна) нею незаконних квазідержавних утворень на сході України - так званих Луганської і Донецької народних республік.

\section{Україна в контексті російської концептуалізації пострадянського простору: «либеральная империя» и «русский мир»}

Увесь спектр українсько-російських відносин після 1991 р. завжди перебував у залежності від російського доктринально-концептуального бачення як перспектив розвитку двостороннього міждержавного співробітництва, так і російського впливу на пострадянський простір загалом. Концептуально пострадянський простір завжди розглядався i розглядається Кремлем як «природна зона міждержавної інтеграції Росії»». Принагідно зауважимо, що ще 1997 р. російські політологи К. Затулін і А. Мігранян запропонували здійснювати керування пострадянським простором шляхом маніпулювання конфліктами на його території. При цьому Російська Федерація чітко усвідомлює ризик того, що глобалізаційні процеси поширяться на пострадянський простір і пострадянські країни «будуть включені у периферію інших центрів інтеграції, в рамках яких вони розвиватимуться абсолютно за іншим вектором» ${ }^{2}$.

Не дивно, що в якості альтернативної пропонується так звана «багатополярна модель глобалізації» як така, що відповідає національним інтересам Росії. Водночас стверджується про невідповідність російським економічним інтересам європейської (а тим паче - євроатлантичної) моделі економічної і політичної інтеграції. Специфікою інтеграційних проектів Російської Федерації $є$ те, що «Росія претендує на статус самостійного центру інтеграції на євразійському просторі. Йдеться про стратегію створення єдиного економічного та гуманітарного простору без формальної інкорпорації у західну систему, у тому

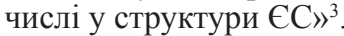

Базові положення російського економічного експансіонізму, які не лише підтримуються Кремлем, але й «творчо» розвиваються і слугують основою для неспівставної з нормами міжнародного права відкритої агресії проти держав-сусідок - як-от України, були оприлюднені восени 2003 р. головою правління РАО «ЕЭС России» А. Чубайсом на шпальтах «Независимой газеты» у вигляді концепції «ліберальної імперії» ${ }^{4}$. У своїй концепції російський політик виходить 3 того, що Росія є єдиним і унікальним лідером на всьому просторі СНД за обсягом економіки і рівнем життя громадян, а упродовж наступних 50 років може і повинна зміцнювати свої позиції. Місія Росії має полягати в побудові ліберальної імперії на основі відповідної ідеології, що відповідає як історичним, геополітичним і моральним засадам держави, так і духовному відродженню народу.

Разом 3 тим «ліберальний імперіалізм» як місія Росії у XXI ст. не треба розглядати 3 точки зору класичного імперіалізму. А. Чубайс обгрунтовував це тим, що Російська держава не збирається порушувати принцип недоторканності кордонів і територіальної цілісності своїх сусідів, а також не буде порушувати загальновизнані норми міжнародного права. Звідси сфери і канали впливу на сусідні країни майбутньої російської ліберальної 
імперії мають бути інші. Насамперед йдеться про сприяння розвитку російської культури і культури інших народів Росії, захист прав і свобод росіян і російськомовних громадян у сусідніх країнах. Це фактично ставить ліберальноімперіалістичний підхід на одну площину з ідеологією і практикою «русского мира», теоретики якого вважають, що форми геополітичної реалізації цієї концепції повинні відповідати реаліям XXI ст. і базуватися на інтеграційній складовій. Вона, у свою чергу, з необхідністю включає Україну як невіддільну частину простору «русского мира» і російської економічної експансії. Тому, безумовно, Російська держава може і повинна сприяти експансії свого бізнесу в сусідні держави, насамперед в Україну.

Поряд з тим, для успішного розвитку інтеграційних проектів на пострадянському просторі, включаючи Україну, провідники «русского мира» не тільки не обмежуються економічною складовою, але й активно використовують потенціал гуманітарної сфери у форматі російської культурної дипломатії. Оновлена Концепція зовнішньої політики Російської Федерації, затверджена 15 лютого 2013 р..$^{5}$, констатує, що «русский мир» - це об'єкт зовнішньої політики російської держави і водночас партнер у впровадженні цієї політики, свого роду «м'яка сила» в ії інструментальному вираженні, яка спирається на можливості громадянського суспільства, інформаційно-комунікаційні, гуманітарні та інші альтернативні класичній дипломатії методи і технології.

Російське керівництво, коли йдеться про посилення впливу Російської Федерації на інтеграційні процеси на пострадянському просторі, обов'язково вказує на необхідність застосування культурних та інформаційних механізмів. Так, у виступі перед керівництвом МЗС РФ 11 лютого 2013 р. президент В. Путін закликав за допомогою механізмів «м’якої сили» зміцнювати позиції російської мови, просувати позитивний імідж Росії за кордоном і використовувати для цього глобальні інформаційні потоки. В іншому виступі, аналізуючи інтеграційні процеси на пострадянському просторі, він наголосив на використанні «м'якої сили» противниками євразійської інтеграції: «...ми можемо зіткнутися із спробами загальмувати інтеграційну роботу. I тут можуть бути використані найрізноманітніші інструменти тиску, включаючи механізми так званої м'якої сили». I далі: «Суверенне право Росії і наших партнерів вибудовувати і розвивати свій інтеграційний проект має бути надійно захищене» ${ }^{6}$.

Необхідно особливо наголосити, що проект «русского мира» з самого початку конституювався як стратегічний. Він має яскраво виражене соціокультурне обрамлення, але зміст пов'язаний із просуванням насамперед геоекономічних і геополітичних інтересів Росії. Про це дуже чітко говорить відомий російський методолог і політтехнолог П. Щедровицький: «Сьогодні як ніколи актуальна розробка геоекономічної стратегії ядра русского мира - Росії як країни-системи. Система Росії повинна не тільки створити єдину торгово-промислову стратегію, але й сформувати нову культуру геоекономічного наступу, захисту і конкуренції, яка враховує зростання ролі людського капіталу і інноваційної економіки в умовах неоіндустріального розвитку». Відповідно, основи стійкості та затребуваності така російська державність може і повинна шукати як у межах «русского мира», так і в політиці конструктивного розвитку його світової мережі ${ }^{7}$. Прибічники концепції «русского мира» стверджують, що цей проект може стати базисом нової цивілізаційної стратегії, побудованої на культурних цінностях. «Русский мир», за їх переконанням, здатний забезпечити новий тип цивілізаційної ідентичності. У результаті цього Росія зможе отримати принципово нову державність, яка спирається на простір культури. Прихильники такого підходу вважають, якщо Митний союз (МС) спрямований передусім на побудову економічної платформи співробітництва, то Євразійський Союз як більш розвинений інтеграційний проект грунтуватиметься на засадах всебічної культурної та гуманітарної взаємодії центру з ідейними периферіями, що поділяють його цінності. Звідси, стратегічна мета Росії - стати системоутворюючою, стрижневою державою «русского мира» ${ }^{8}$.

Окреслене ідеологічне підгрунтя пояснює поведінку Російської Федерації в сучасних умовах. 3 одного боку, вона ставить за мету розвинутися в нову імперську державу на базі Єдиного економічного простору (ЄЕП), а також Євразійського Союзу, як інтеграційного об'єднання нового покоління, який має велючати не лише Російську Федерацію, Білорусь, і Казахстан, але й Україну, і в якому житимуть за продиктованими Москвою спочатку еко- 
номічними, а потім і політичними правилами. 3 іншого, Росія прагне повернути собі притаманні Радянському Союзу в епоху «холодної війни» функції наддержави.

Такі обставини і підходи мають як мінімум три принципових наслідки. По-перше, активно розробляються концепції формування навколо Росії альтернативного - євразійського - центру впливу. По-друге, інтеграція на пострадянському просторі набула своїх специфічних рис, значною мірою зумовлених першим наслідком. По-третє, Москва прагне максимально протидіяти поширенню європейського і євроатлантичного інтеграційних векторів на Україну, яку розглядає у якості виключно своєї сфери економічного, політичного і культурного впливу.

\section{Україна і євразійські інтеграційні плани Кремля}

Проаналізовані вище російські концептуальні засади інтеграції пострадянського простору Москва прагнула втілити у конкретні проекти. Це знайшло продовження у відповідній політиці Російської Федерації і з огляду на неї в зростаючому тиску на Україну в результаті створення Митного і Євразійського союзів, а також використання в російських інтересах енергетичного (насамперед - газового) чинника9 ${ }^{9}$ Першим кроком до формування митного об’єднання було підписання в січні 1995 р. Угоди про Митний союз між Російською Федерацією і Республікою Білорусь, до якого пізніше приєдналися Казахстан і Киргизстан, а в 1999 р. - Таджикистан. 10 жовтня 2000 р. був підписаний Договір про створення Євразійського економічного співтовариства (СврАзЕС) ${ }^{10} .3$ травня 2002 р. статус спостерігачів при ЄврАзЕС дістали Україна і Молдова, а з січня 2003 р. - Вірменія. Такий статус наданий також Міждержавному авіаційному комітету (МАК) і Свразійському банку розвитку (САБР). Швидкі зміни процесів економічної інтеграції на просторі СНД під впливом Росії були пов'язані з появою у січні 2010 р. і прискореним розвитком Митного союзу і Єдиного економічного простору Росії, Казахстану та Білорусі.

На думку вітчизняних експертів, зокрема економіста і політика П. Гайдуцького, залучення України до Митного союзу було вигідне Російській Федерації з кількох міркувань: «По-перше, не допускаючи зближення України з іншими інтеграційними формуваннями, передусім з СС, Росія обмежує зміцнення конкурента. По-друге, втягнувши Україну в свої інтеграційні формування - Митний союз, ЄврАзЕС, Росія зміцнює свої конкурентні позиції» ${ }^{11}$.

У такому випадку становлення проросійського євразійського центру інтеграційного впливу привертає увагу з огляду на ряд концептуальних схем і практичних кроків 3 російського боку. Зокрема, сфокусуємо увагу на точці зору Р. Грінберга про можливість двох сценаріїв розвитку пострадянського простору: I - економічний розвиток у ролі периферії; II - розвиток на основі інтеграційних процесів відтворення «на євразійському просторі самостійного ядра економічної могутності» ${ }^{12}$. Азійський інтеграційний вектор пов'язується із відновленням статусу Росії як наддержави і, відповідно, самостійного «центру сили». У якості інституціональної оболонки для реалізації такої ідеї розглядається варіант саме $Є Е \Pi^{13}$.

Сама розробка і початок реалізації цього проекту (Україна у вересні 2003 р. підтримала його реалізацію спільно з Росією, Білоруссю і Казахстаном, а на Ялтинському саміті 23 листопада 2003 р. чотири держави підписали угоду про створення ЄЕП. Вона була синхронно ратифікована 20 квітня 2004 р. Верховною Радою України та Федеральними Зборами Російської Федерації) фактично стала логічним продовженням прагматичного курсу Кремля, спрямованого на зміцнення економічних позицій Росії на пострадянському просторі ${ }^{14}$. Це показово ілюструють слова російського президента В. Путіна, який наголошував, що важливим прагматичним елементом угоди про ЄЕП «повинна стати відмова від прагнення до суцільної інтеграції всіх пострадянських держав і орієнтація на посилення інтеграційного ядра», а, відповідно, «створення єдиного економічного простору є стратегічним завданням для Росії, головною метою чого $є$ підвищення конкурентоспроможності кожного з членів СЕП» ${ }^{15}$. Фактично подібні засадничі положення щодо ЄЕП В. Путін, тоді ще прем'єр-міністр, виклав у газеті «Известия» в статті, приуроченій до старту 1 січня 2012 р. «надзвичайно важливого інтеграційного проекту - Сдиний економічний простір Росії, Білорусі та Казахстану» ${ }^{16}$. 
Як резонно зазначив відомий український економіст А. Гальчинський: «Запропонована російською стороною модель формування ЄЕП виходить за межі суто економічного співробітництва. Його реалізація передбачає неодмінну політичну (а також військову) інтеграцію чотирьох країн. У даному разі фактично йдеться про утворення на чолі з Росією функціонально відособленого, за своєю суттю - протилежного ЄС інтеграційного об'єднання, розширене відтворення ЄврАзЕс» ${ }^{17}$.

На базі ЄЕП ЄврАзЕС Росія пропонувала створення Євразійського економічного союзу і потім - Свразійського Союзу як інтеграційного об'єднання нового покоління, відкритого для вступу в нього інших держав Євразії. Декларація про створення Євразійського Союзу була підписана 18 листопада 2011 р. в Москві лідерами Росії (Д. Медвєдєвим), Білорусі (О. Лукашенком) і Казахстану (Н. Назарбаєвим). Водночас це вповні відповідає оновленій Концепції зовнішньої політики Російської Федерації від 15 лютого 2013 р. Там відзначено, що «Росія вважає пріоритетним завдання формування Свразійського економічного союзу, покликаного не тільки максимально задіяти взаємовигідні господарські зв'язки на просторі СНД, але й стати моделлю об'єднання, яка визначає майбутнє країн Співдружності, відкритої для інших держав. Новий союз, що будується на універсальних інтеграційних принципах, покликаний стати ефективною з'єднувальною ланкою між Європою і Азійсько-Тихоокеанським регіоном ${ }^{18}$. При цьому відносини з Україною передбачалося вибудовувати як з пріоритетним партнером у рамках $\mathrm{CHД,} \mathrm{а} \mathrm{також} \mathrm{сприяти} \mathrm{ії}$ підключенню до поглиблених інтеграційних процесів. Це цілком зрозуміло, адже показники зовнішньої торгівлі товарами і послугами між Україною і Російською Федерацією в 2011-2013 pр. були найбільшими за всі 25 років новітньої української державності: 2011 р. - 55,5 млрд. дол., 2012 р. - 51,4 млрд. дол., 2013 р. - 41,9 млрд. дол. ${ }^{19}$

Євразійський економічний союз (САЕС) був створений на основі договору, підписаного 29 травня 2014 р. в Астані. 31 січня 2015 р. цей договір вступив у силу, об'єднавши Білорусь, Казахстан і Росію. До нього приєдналися Вірменія (2 січня 2015 р.) і Киргизстан (14 травня 2015 р.).

Обережне ставлення України до подібного роду проектів зрозуміле, але разом з тим ми не можемо відмовлятися і від ефективної співпраці з Російською Федерацією й інтеграційними об'єднаннями, які створюються під іiї егідою. Безумовно, така позиція України 3 огляду на зростання ролі євроінтеграційного вектора у зовнішній політиці нашої держави викликала серйозне занепокоєння Кремля, який розглядав ії як серйозну загрозу реалізації своїх євразійських інтеграційних планів. Оскільки організаційна робота по створенню фундаменту Євразійського союзу мала завершитися, на думку офіційної Москви, до 2015 р., то стає вповні зрозумілим, чому Росія не лише прагнула, щоб Україна до того часу визначилася з вектором інтеграції, але й вчинила небачений тиск на нашу державу, включаючи збройну агресію і відторгнення частини території.

Пріоритетність для Росії геополітичної складової, як визначального чинника стимулювання, прискорення і скерування у відповідному руслі інтеграційних процесів на переважній частині пострадянського простору, веде до намагання Москви розглядати його як зону своїх «легітимних» життєво важливих інтересів. Доказів цього останнім часом не бракувало, а особливо наочно відповідні положення були продемонстровані політикою Кремля у контексті реакції на Європейську революцію, революцію Гідності та повалення правлячого режиму В. Януковича в Україні (події 21 листопада 2013 - 22 лютого 2014 рр.). Російська Федерація фактично розв'язала проти України неоголошену війну, здійснивши у формі анексії окупацію Криму, провокуючи і всіляко підтримуючи військові дії незаконних збройних формувань сепаратистів на Донбасі (Луганська і Донецька області).

\section{Особливості свразійських інтеграційних процесів і Україна}

Усі наведені вище обставини концептуально-теоретичного і прикладного плану позначилися на специфіці інтеграційних процесів та зумовили низку особливостей, якими вони супроводжуються на пострадянському просторі в умовах геополітичних змін і масштабних трансформаційних зрушень кінця XX - початку XXI ст. Виокремимо, спираючись на наукові, дослідницькі, аналітичні доробки різних авторів, а також власні узагаль- 
нення, найголовніші, на наш погляд, особливості інтеграційної складової на пострадянському просторі.

Перша. Інтеграція на основі дезінтеграції, тобто відцентрових процесів, які спостерігалися після розпаду Радянського Союзу. Прагнення Росії відігравати роль як інтегруючого ядра, так і єдиного «центру сили» на теренах колишнього СРСР, нав'язати свій пострадянський інтеграційний проект наштовхнулося на різне сприйняття і навіть опір з боку нових незалежних держав. Це пояснювалося з самого початку різновекторністю інтеграційних орієнтацій державних акторів пострадянського простору: частина 3 них - наприклад, країни Балтії - були зорієнтовані на європейський і євроатлантичний інтеграційні вектори, а інші - зокрема, Білорусь і Казахстан - вибрали проросійський євразійський інтеграційний курс. Щодо України, то ії політика тривалий час «витанцьовувала» між європейським і євразійським напрямками інтеграції. Свідченням цього стало підписання Україною в 1994 р. Угоди про співробітництво з СС, а в 2003 р. - Угоди про створення ЄЕП з Російською Федерацією, Білоруссю і Казахстаном. Наша держава навіть намагалася протиставити російським свої інтеграційні проекти. Насамперед йшлося про створені в 1992 р. ОЧЕС (Організація Чорноморського економічного співробітництва - Азербайджан, Албанія, Болгарія, Вірменія, Греція, Грузія, Молдова, Росія, Румунія, Сербія, Туреччина, Україна) і в 1997 р. ГУАМ (Організація за демократію і економічний розвиток - Грузія, Україна, Азербайджан, Молдова), у яких Україні відводилася роль регіонального лідера. Однак вони так і не змогли реалізувати свій економічний і політичний потенціал та не стали новими успішними інтеграційними об'єднаннями, у тому числі на просторі СНД.

Тільки в 2014 р. відбувся остаточний вибір нашої держави на користь євроінтеграції, результатом чого стало підписання (21 березня і 27 червня) і ратифікація (16 вересня) Угоди про асоціацію між Україною та $\mathrm{CC}^{20}$. Повністю Угода про асоціацію набере чинності після іiі ратифікації усіма Сторонами, в перший день другого місяця, що настає після дати здачі на зберігання до Генерального секретаріату Ради Європейського Союзу останньої ратифікаційної грамоти або останнього документа про затвердження. На початок грудня 2015 р. Угода ратифікована Україною та Європейським парламентом 16 вересня 2014 р., а також такими країнами-членами СС: Румунія - 9 липня 2014 р., Литва - 11 липня 2014 р., Латвія - 18 липня 2014 р., Болгарія - 28 липня 2014 р., Мальта - 21 серпня 2014 р., Словаччина - 16 жовтня 2014 р., Естонія - 13 листопада 2014 р., Швеція - 26 листопада 2014 р., Угорщина - 5 грудня 2014 р., Хорватія - 18 грудня 2014 р., Данія - 18 грудня 2014 р., Ірландія - 27 січня 2015 р., Польща - 2 березня 2015 р., Велика Британія - 19 березня 2015 р., Люксембург - 12 квітня 2015 р., Іспанія - 15 квітня 2015 р., Португалія - 23 квітня 2015 р., Фінляндія - 24 квітня 2015 р., Словенія - 21 травня 2015 р., Німеччина - 27 травня 2015 р., Франція - 7 липня 2015 р., Австрія - 31 липня 2015 р., Італія - 29 вересня 2015 р., Чехія 27 жовтня 2015 p. $^{21}$

Друга. Надзвичайно потужна залежність інтеграційних проектів і їх реалізації від російського енергетичного чинника. Це має пряме відношення до російсько-українського співробітництва. Так, за січень - червень 2014 р. частка енергоносіїв у структурі загального імпорту з Російської Федерації в Україну становила $62,2 \%$, а через рік вона скоротилася до 44,9\% 22 . Іншими словами, для Росії надзвичайно великої ваги набуває боротьба за енергоносії і, відповідно, за енерготранспортні коридори, в якій Україні відводяться дуже серйозні ставки з точки зору регіонального глобального вимірів проблеми. Прагненням Росії $є$ не тільки постачати власні енергоносії переважним чином до Європи та контролювати шляхи їх поставок (а отже отримувати прибутки від транзиту), але й перебрати на себе роль єдиного посередника в поставках газу та нафти з країн Каспію й Центральної Азії ${ }^{23}$. Цим пояснюється і надмірна політизація Кремлем енергетичного чинника у відносинах насамперед з Києвом, а також намагання використовувати його як засіб тиску на $\mathrm{CC.}$

Разом 3 тим, Росія як «газова імперія» може внаслідок яскраво вираженої імперської політики, яка здійснюється на основі в тому числі «енергетичного шантажу», сама себе загнати в глухий кут. Так, у відповідь на розв'язану Кремлем війну проти України на початку квітня 2014 р. Держсекретар США Джон Керрі заявив, що його країна готова розпочати постачання газу до Європи вже у 2015 р., а президент США Барак Обама підтвердив, що американська влада готова дати всі необхідні дозволи на експорт газу в обсягах, необхід- 
них для щоденних потреб Європи. Водночас упродовж 2014-2015 рр. відбувалося стрімке падіння ціни на нафту на світовому ринку: у 2014 р. - нижче 60 дол. США за барель, а в 2015 р. такий процес призвів до того, що вартість нафти марки Brent 14 грудня 2015 р. опустилась до 36,85 дол. США, обновивши мінімум з грудня $2008 \mathrm{p}^{24}$. Це вже завдає суттєвих збитків Росії, бюджет якої побудований на основі відповідної ціни 100 дол. США за барель у 2014 р. і 96 дол. США за барель у 2015 р. Бюджет Російської Федерації втрачає 80 млрд. рублів (близько 2 млрд. дол. США) від кожного падіння ціни на нафту на 1 долар. Не можна також не бачити на перспективу негативного впливу на російську економіку і результатів «сланцевої революції» ${ }^{25}$.

Tpemя. Із відновленням статусу Росії як наддержави, самостійного «центру сили» пов'язується також азійський інтеграційний вектор (на цьому, зокрема, акцентує увагу Н. Арбатова) $)^{26}$. Це означає, що в контексті зближення Росії та Китаю (Шанхайська Організація Співпраці - ШОС - 2001 р., російсько-китайські газові домовленості 2014 р.) набуває реальних ознак біполярна модель розвитку Схід - Захід. У цьому плані показовим був саміт Росія - СС у травні 2009 р. в Хабаровську. Кремль свідомо вибрав місце проведення саміту, сигналізуючи «європейським партнерам», що у Росії $є$ ще один вектор розвитку. Початок будівництва нафтопроводу Сковородіно - Мохай, карта Росії, подарована президентом Д. Мєдвєдєвим єврокомісару Х. Солані, а головне - «реальне дихання Китаю», більш ніж очевидне в Хабаровську, - ось знакові сигнали керівництва Російської Федерації лідерам $\mathrm{EC}^{27}$. Сигнали, які набули нової особливої актуальності після анексії Росією Криму, розв'язання війни з Україною і введення проти Москви санкцій з боку СС, США, Японії, Австралії, Канади, Швейцарії.

Четверта. Неспроможність СНД (як і будь-якого іншого пострадянського інтеграційного проекту) відігравати консолідуючу роль в об'єднанні колишніх радянських республік.

Від часу створення СНД, на що звертають увагу українські аналітики, з’ясувалися дві діаметрально протилежні ідеології щодо сенсу та перспектив розвитку цієї організації. Для України ставлення до СНД було схожим на ставлення до організації, в якій Україна перебуватиме лише до часу подальшої інтеграції з Об'єднаною Європою. Тобто, Україна розглядає СНД як механізм «цивілізованого розлучення» республік колишнього СРСР. Російська Федерація, навпаки, розглядала і розглядає СНД як проміжну форму відновлення колишньої імперської державності, а в існуючому виді - як сферу домінування своїх інтересів $^{28}$. У цій дихотомії, яка також пов'язана з низкою інших особливостей пострадянського інтеграційного чинника, приховані такі основні причини нежиттєздатності та нестабільності СНД:

а) нерівноправність відносин між країнами СНД, а також претензії Росії на політичне, економічне, інформаційне та соціокультурне домінування;

б) намагання Москви розглядати весь пострадянський простір як зону «легітимних» життєво важливих своїх інтересів;

в) несумісність вимог Російської Федерації щодо координації зовнішньої та економічної політики країн СНД з повним ігноруванням нею інтересів і пріоритетів країнпартнерів;

г) постійні спроби Кремля сформувати в рамках СНД новий військово-політичний блок чи систему колективної безпеки під своєю егідою, які б включили значно більший простір (у тому числі й український), ніж створений у 1992 р. Ташкентський пакт - Організація договору про колективну безпеку за участі Росії, Білорусі, Biрменії, Казахстану, Киргизстану і Таджикистану;

д) стратегічний курс Росії на розбудову наддержавних структур СНД під своїм жорстким контролем і прогресуючу інтеграцію нових незалежних держав у новий потужний проросійський геополітичний блок ${ }^{29}$.

П'ята. Пріоритетність, насамперед для Росії, геополітичної складової як визначального чинника стимулювання, прискорення і скерування у відповідному руслі інтеграційних процесів на переважній частині пострадянського простору. Це зумовило готовність Кремля на силові кроки з метою реалізації своїх інтеграційних і геополітичних схем на євразійському пострадянському просторі. На нашу думку, приблизно в середині першого десятиліття XXI ст. Росія завершила своєрідну «геополітичну паузу» і перейшла до від- 
новлення надпотужних міжнародних позицій. Свідченням цього став хоча б виступ В. Путіна на конференції з безпеки в Мюнхені (2007 р.) і тиск на НАТО з метою недопущення прийняття на Бухарестському саміті (2008 р.) Планів дій України та Грузії по членству в Альянсі. Взагалі в ході саміту НАТО в Бухаресті Російська Федерація по суті перекреслила принципи Основоположного Акту «Росія - НАТО», підписаного в 1997 р., згідно 3 яким Росія визнавала право будь-якої країни Європи самостійно забезпечувати свою безпеку, тобто вступати чи не вступати до тих чи інших оборонних союзів, а НАТО натомість гарантувало, що на території нових його членів не розміщуватиметься ядерна зброя. Яскравим прикладом силової геополітичної активності Кремля стала серпнева (2008р.) російсько-грузинська війна, окупація і анексія Росією Криму в березні 2014 р. та так звана гібридна війна проти України, яка знайшла вираження, зокрема, у всебічній підтримці воєнних і сепаратистських дій на сході України.

Шоста. Наявність надмірного конфліктогенного потенціалу на просторі СНД у зв'язку з охарактеризованою вище гегемоністською спрямованістю політики Росії та відповідних їй інтеграційних устремлінь. Важливий чинник, який зумовив агресивну експансіоністську поведінку Росії спочатку щодо Грузії, а потім й України - історична обумовленість конфліктів в умовах розпаду і після розпаду імперій. Саме процесами пострадянського імперського синдрому спробував пояснити причини конфліктів після розпаду СРСР український політолог В. Карасьов: «Відносини з РФ засвідчили, що Росія ніколи не погодиться на те, щоб на пострадянському просторі, на колишньому імперському просторі формувалися інші держави з іншими політичними моделями і з іншими геополітичними орієнтаціями. Росія ... розуміє, що формування нових, сильних, серйозних націй на постімперському просторі розмиває його, формує нові регіональні конфігурації, i, головне, що РФ ризикує втратити пояс напівдержав (сірих зон, буферних зон), які вона завжди розглядала як пояс безпеки» ${ }^{30}$.

Прогнозованість конфліктів на постімперському просторі підкреслив і політичний аналітик В. Горбач: «Коли радянська імперія відходила з колишніх республік, вона робила «закладки», - такі конфлікти для того, щоб геополітично впливати на них, щоб мати можливість тримати на цих територіях війська у вигляді миротворчих сил, щоб мати «больові точки» у новостворених країнах, на які можна тиснути, і вони вже рефлекторно реагуватимуть таким чином, як потрібно тому, хто тисне» ${ }^{31}$.

На наш погляд, і ми тут солідарні з точкою зору політтехнолога В. Бали ${ }^{32}$, ще події серпня 2008 р. засвідчили, що Росія так і не змогла позбавитися «комплексу імперії». Щось подібне ми вже переживали, коли Кремль заявив претензії на свій ексклюзивний особливий вплив на країни «ближнього зарубіжжя», до яких було включено всі країни колишнього СРСР, в тому числі Україну. Не дивно, що цей «імперський комплекс» вийшов на чільне місце в 2014 р. як своєрідна агресивна рефлексія на події в Україні та довкола неї (Європейська революція, революція Гідності, крах правлячого промосковського режиму В. Януковича, підписання Україною Угоди про Асоціацію з СС), які загрожували остаточно вирвати Київ з-під впливу Москви.

Фактично відзначені особливості, і ми свідомі цього, далеко не вичерпуються переліченими. Це з одного боку. А з іншого вони об'єктивно виводять нас на необхідність аналізу «української перспективи» в інтеграційній складовій на пострадянському просторі. Відзначимо, що з точки зору історичного досвіду входження українських земель до складу різних держав, як правило, надавало їх розвитку потужного імпульсу. Так було з Польщею в XIV - середині XVII ст. і Росією середини XVII - початку XX ст. Але - навпаки - виокремлення українського сегменту вело до значної дестабілізації політичної системи метрополії, а то й до іiї остаточного занепаду. Прикладом можуть слугувати Польща другої половини XVII-XVIII ст. і Радянський Союз 1990-1991 pp. Однак характерна риса кожного $з$ наведених інтеграційних варіантів - Україна була в них не суб'єктом, а об'єктом міжнародних відносин. Звідси, з позицій «українського чинника» в пострадянській інтеграції постає її надзвичайно важлива особливість: Україна вперше не просто заявила про себе у якості суб'єкта сучасних міжнародних відносин, але й реального гравця, який має власну точку зору щодо інтеграційних побудов пострадянського типу, і міжнародного актора, який хоч і в ході складних внутрішньо- та зовнішньополітичних колізій, але все ж зробив вибір на користь європейського інтеграційного вектора. 


\section{Висновки}

Події в Україні наприкінці 2013 - початку 2014 рр. - курс нашої держави на підписання Асоціації з СС і раптова для суспільства і партнерів України відмова від нього, Європейська революція, новий український Майдан і революція Гідності, які запустили механізм перезавантаження влади - мали колосальне значення. Перспектива реального виведення України з інтеграційної орбіти Росії викликала потужну комплексну реакцію Кремля, яка створила серйозну загрозу територіальній цілісності та суверенітету України. Ядром іiї стала фактична російська інтервенція й анексія Криму, всебічна підтримка Москвою сепаратистських сил на Сході України і фактичне розв'язання неконвенційної («гібридної») війни проти нашої держави. У відповідь політико-дипломатичні та військові кроки України мали своїм наслідком у тому числі й те, що Верховна Рада України 27 січня 2015 р. визнала Росію державою-агресором і прийняла рішення про відсіч збройній агресії Російські Федерації та подолання ії наслідків ${ }^{33}$.

Агресивна й анексіоністська політика Російської Федерації щодо України 2014 2015 pр. зі всією очевидністю показали, що Росія, відчуваючи останнім часом зростання своєї потужності, перш за все енергетичної та військової, хоче суттєво посилити власні позиції в координатах динамічної системи міжнародних відносин початку XXI ст. Це спричинило зовнішньополітичну активізацію Росії на всіх напрямках і насамперед у сфері відновлення свого впливу на пострадянському просторі. Шляхи і методи реалізації такої політики, зокрема силою зброї й ведення «гібридної» війни, анексії та включення Криму до складу Росії, підтримки незаконних сепаратистських угруповань на Сході України фактично на основі стратегії «повзучої легітимації тероризму», можуть завести Москву в глухий кут, уже зараз завдаючи небаченого удару по всьому спектру російсько-українських відносин як на міждержавному, так і суспільному зрізах. Водночас відверто експансіоністська політика Росії щодо України повинна послужити серйозним уроком для нашої держави і суспільства.

Тільки активна діяльність на міжнародній арені на основі врахування національних пріоритетів і реальних можливостей Української держави в поєднанні зі зваженою консолідованою й ефективною внутрішньою політикою і прогнозованим прагматичним проєвропейським зовнішньополітичним курсом може забезпечити позитивний імідж і гідне місце Україні на міжнародній арені. Потрібно покінчити з ситуацією «внутрішнього дисбалансу», яка для нашої держави особливо небезпечна з точки зору програми світового простору як єдиного організму, що грунтується на визнанні світового лідерства в якості провідної цінності світової політики. За справедливим судженням російського науковця I. Кефелі, «твердим ядром цієї програми є твердження, згідно якому в світовому простоpi існують ключові зони, а контроль над ними забезпечує світове лідерство» ${ }^{34}$. У нашому випадку Росія прагнула і надалі прагнутиме зберегти контроль над ключовою зоною євразійського геополітичного простору. Звідси, особлива вразливість України була не стільки в тому, на кого з міжнародних акторів (Російську Федерацію, Свропейський Союз чи США) вона робила ставку, а, насамперед, у тактичній і стратегічній невизначеності нашої офіційної позиції та лінії поведінки в суперечливих конфліктогенних ситуаціях у ключових геополітичних зонах. Свропейський вибір як наслідок революційних потрясінь 2013-2014 pр. не лише має всі можливості ліквідувати загрозливу проблему «внутрішнього дисбалансу», але й кардинально зміцнити міжнародні позиції України.

Уповні погоджуємося із знаним українським політологом М. Михальченком ${ }^{35}$, що докорінний зовнішньополітичний вибір у новій ситуації переструктуризації пострадянського світу тісно пов'язаний зі світоглядною переорієнтацією більшості українського суспільства на новий тип мислення - цивілізаційний (замість ідеологічного, який домінував у період «холодної війни»). Якщо виходити з позицій ідеологічного підходу, ситуація змінилася докорінно: Схід, тобто Росія, прагне підкорити Україну.

Цивілізаційний спосіб мислення «працює» не в площині «класовий ворог - світова війна», а в площині конкуренції ідей, технологій, способів життя, взаємодопомоги, тобто щодо цивілізаційних цінностей життя: яка країна, об'єднання країн забезпечують вищий рівень життя і соціального захисту. I тут доведеться ламати старі стереотипи мислення: хто ворог, а хто цивілізований партнер; які норми взаємовідносин націй у глобалізова- 
ному суспільстві; чи потрібна нова «холодна війна» і відродження імперій, новий тип і стиль взаємовідносин великих, середніх і малих країн тощо. На перспективу для України важливо не тільки зробити свій вибір, підписавши Угоду про Асоціацію з Свропейським Союзом, але і відстояти його шляхом успішної інтеграції до європейської системи економічних, політичних, громадянських цінностей.

Необхідно також звернути особливу увагу на той факт, що характер російсько-українських відносин у 2013-2015 pp. і необгрунтоване збройне втручання Росії у внутрішні справи України свідчить про вступ у завершальну фазу великої геополітичної битви за український інтеграційний геополітичний і геоекономічний простір. Важливе стратегічне завдання України - вийти з найменшими втратами з надзвичайно складної і загрозливої ситуації, у якій вона опинилася у зв'язку з відходом від євразійського інтеграційного вектору, наслідком чого стала російська окупація Криму, дестабілізація ситуації на сході України і розв'язана Кремлем російсько-українська війна. Все це ставить на порядок денний нагальну проблему серйозного переосмислення не лише загальних концептуальних зовнішньополітичних засад Української держави, але й конкретно іiї відносин з Російською Федерацією з точки зору загальної стратегії і тактичних кроків по ії̈ реалізації.

${ }^{1}$ Стенограмма заседания Европейского клуба «Интеграция на постсоветском пространстве» 28 июня 2005 г. - URL: http://www.kreml.org/other/90630818 (дата звернення: 04.01.2016).

${ }^{2}$ Там само.

${ }^{3}$ Див.: Україна та проект «русского мира». Аналітична доповідь. - К.: НІСД, 2014. - С. 70.

4 Чубайс А. Б. Миссия России в XXI веке // Независимая газета. - 2003. - 1 октября.

${ }^{5}$ Концепция внешней политики Российской Федерации. Утверждена Президентом Российской Федерации В. В. Путиным 12 февраля 2013 г. - URL: http://www.brunei.mid.ru/doc/kontsep_vneshn_ polit_rf.pdf (дата звернення: 03.01.2016).

${ }^{6}$ Цит. за: Україна та проект «русского мира». Аналітична доповідь. - К.: НІСД, 2014. - С. $63-64$.

${ }^{7}$ Щедровицкий П. Русский мир. Возможные цели самоопределения / П. Щедровицкий // Русский архипелаг: сетевой проект «Русского мира» - URL: http://www.archipelag.ru/authors/shedrovicky_ petr/?library=2015 (дата звернення: 03.01.2016).

${ }^{8}$ Україна та проект «русского мира». Аналітична доповідь. - К.: НІСД, 2014. - С. 67-68.

${ }^{9}$ Крамар О. Газпром - 2 // Український тиждень. - 2012. — № 47 (264).

${ }^{10}$ Договор об учреждении Евразийского экономического сообщества от 10 октября 2000 г. (с изменениями от 25 января 2006 г. и 6 октября 2007 г.) - URL: http:/www.evrazes.com/docs/view/3 (дата звернення: 04.01.2016).

${ }^{11}$ Гайдуцьький П. Україна і Митний союз: проблеми інтеграції // Дзеркало тижня. - 2013. - № 11. - 22-29 березня.

12 Гринберг Р. Постсоветское пространство: возможности и пределы // Информационно-аналитический бюлетень / Центр проблем интеграции ИМЭИПИ РАН. - 2005. - № 2. - С. 10-16.

${ }^{13}$ Глазьев С. Ю. О целях, проблемах и мерах государственной политики развития и интеграции: Научный доклад 29 января 2013 г. - М.: РАН, 2013. - С. 31-34, 45-56.

${ }_{14}$ Див. напр.: Малик Я. Й. Інтеграційні процеси на пострадянському просторі: Навчальний посібник / Я. Й. Малик, Б. Д. Вол, Ю. С. Занько. - Львів: ПАІС, 2007. - 68 с.

15 Україна в інтеграційних процесах на пострадянському просторі: моделювання альтернатив. К.: НІСД, 2013. - С. 12.

${ }^{16}$ Путин В. Новый интеграционный проект для Евразии - будущее, которое рождается сегодня // Известия. - 2011. - 3 октября.

${ }^{17}$ Стратегія євроінтеграції та питання участі України у формуванні Єдиного економічного простору (аналітичні оцінки). - К.: НІСД, 2003. - С. 16.

${ }_{18}$ Концепция внешней политики Российской Федерации. Утверждена Президентом Российской Федерации В. В. Путиным 12 февраля 2013 г. - URL: http://www.brunei.mid.ru/doc/kontsep_vneshn_ polit rf.pdf (дата звернення: 03.01.2016).

$\overline{19}$ Торгово-экономическое сотрудничество между Украиной и Россией - URL: http://russia.mfa. gov.ua/ru/ukraine-ru/trade (дата звернення: 27.01.2016).

${ }^{20}$ Угода про асоціацію між Україною, з однієї сторони, та Європейським Союзом, Європейським співтовариством $з$ атомної енергії і їхніми державами-членами, з іншої сторони - URL: http://www. kmu.gov.ua/kmu/docs/EA/00_Ukraine-EU_Association_Agreement_\%28body\%29.pdf (дата звернення: 03.01.2016).

${ }^{21}$ Угода про асоціацію між Україною та Європейським Союзом - URL: https://uk.wikipedia.org/ wiki/ (дата звернення: 11.12.2015). 
22 Торгово-экономическое сотрудничество между Украиной и Россией. - URL: http://russia.mfa. gov.ua/ru/ukraine-ru/trade (дата звернення: 27.01.2016).

${ }^{23}$ Мартинюк $B$. Російсько-грузинський конфлікт: зміна тенденцій поставок енергоносіїв 3 Каспійського регіону // Українська правда - URL: http://www.pravda.com.ua/articles/2008/09/19/3562853/ (дата звернення: 03.01.2016).

${ }^{24}$ Ціни на нафту марки Brent на IPE на 31.12 .2014 (02:00). - URL: http://www.rbc.ua/ukr/oil (дата звернення: 03.01.2015); Цены на нефть упали до нового семилетнего минимума. - URL: http://www. rbc.ua/rus/news/tseny-neft-upali-novogo-semiletnego-minimuma-1450093580.html (дата звернення: 15.12.2015).

${ }^{25}$ Російська енергетична імперія, що спотикається. - URL: ipress.ua/.../rosiyska_energetychna imperiya_shcho_spotykaietsya_3075 (дата звернення: 03.01.2016).

${ }^{26}$ Арбатова 2006. - № 1. - URL: http://www.globalaffairs.ru/number/n_6315 (дата звернення: 02.01.2016).

27 Маслов О. Ю. Новая российская энергетическая доктрина: от анклавно-архаичной «энергетической сверхдержавы» к глобальной энергетической Хартии. - URL: http://www.polit.nnov. ru/2009/05/24/energoconcept8/ (дата звернення: 03.01.2016).

${ }_{28}$ Україна 2000 і далі: геополітичні пріоритети та сценарії розвитку. - К.: НІСД, 1999. - С. 60.

29 Там само. - С. 57-58.

${ }^{30}$ Російсько-грузинський конфлікт: причини та наслідки для Європейської безпеки: матеріали експертної дискусії 14 серпня 2008 р. / За заг. ред. Ю. Г. Рубана. - К.: НІСД, 2008. - С. 9-10.

${ }^{31}$ Там само. - C. 31 .

${ }^{32}$ Бала В. Що ж насправді відбувається в Грузії. - URL: http://blog.liga.net/user/bala/article/1912. aspx (дата звернення: 03.01.2016).

33 Постанова Верховної Ради України «Про Звернення Верховної Ради України до Організації Об'єднаних Націй, Європейського Парламенту, Парламентської Асамблеї Ради Європи, Парламентської Асамблеї НАТО, Парламентської Асамблеї ОБСЄ, Парламентської Асамблеї ГУАМ, національних парламентів держав світу про визнання Російської Федерації державою-агресором» // Відомості Верховної Ради. - 2015. - № 10. - С. 68; Постанова Верховної Ради України «Про Заяву Верховної Ради України «Про відсіч збройній агресії Російської Федерації та подолання іії наслідків» // Відомості Верховної Ради. - 2015. - № 22. - С. 153.

${ }^{34}$ Кефели И. Ф. Философия геополитики. - СПб.: Петрополис, 2007. - С. 34.

${ }^{35}$ Михальченко M. Україна зробила перший крок, що далі? // Наукові записки Інституту політичних і етнонаціональних досліджень ім. І. Ф. Кураса НАН України. - 2013. - 6 (68) (листопад-грудень). - С. 299-300. 